\title{
Společenský diskurs o genderové rovnosti ve vzdělávání v polských školkách. Nástin problematiky
}

\author{
Małgorzata Kaliszewska
}

Univerzita Jana Kochanowského v Kielcích

Cílem tohoto článku je představit mediální diskurs o genderové rovnosti ve vzdělávání ve školkách na pozadí mediálního diskursu o genderové ideologii a prizmatem dualistického paradigmatu, které se v pedagogice objevilo teprve nedávno, a to díky Lechu Witkowskému. Polský profesor využil pojmy užívané Norbertem Eliasem v sociologii, toto paradigma pro potřeby pedagogiky rozšíril a vytvořil z něj nástroj poznávání komplikovaného světa a situace učitele v něm (Witkowski, 2013; Elias, 2003). Podle Witkowského (2013) se v Eliasově díle (Elias, 2003) dočteme, že

dualismem je zde chápán princip naplňování sociálních situací rysy komplikovanosti, která vzniká mísením odlišných vlivů a ze střetu toho, co pomíjí a mizí, s tím, co ohlašuje svůj příchod, co prrímo zvěstuje novou epochu, ačkoli ještě bez konkrétních obrysů a zralých projevů. (Witkowski, 2013, s. 99)

Citovaný autor vysvětluje, že ambivalentnost je „strukturním rysem odkazujícím $\mathrm{k}$ bipolárnímu systému, $\mathrm{v}$ němž funguje mechanismus (pravidlo) oscilace, zdůrazňující nejednoznačnost, dvoustrannost a nutnost vyhýbat se přemíře i nedostatku v okamžiku, kdy neexistuje zlatý střed“ (Witkowski, 2013, s. 159). Witkowski (2013, s. 152) zdůrazňuje, že perspektiva dualismu již byla v obecné pedagogice využita (Gnitecki, 1994), ale její potenciál nebyl využit. Witkowského teze se staly také součástí pedeutologie, díky př́íručkám Kwiatkowské $(2005,2008)$ hrají důležitou roli v sociální pedagogice (Marynowicz-Hetka, 2006) a objevují se v analýzách Andrukowicze (2006), Dudzikowé (1998) a Jaworské-Witkowské (2009).

Druhým cílem naší práce je představit problémy a nebezpečí spojená s uváděním nových témat do vzdělávání malých dětí, což je dnes z důvodu rychle se měnící reality nezbytné. Tyto zásahy však musí být promyšlené a pečlivé, nesmí být protiprávní, aby nenarušily vývoj nejmladších dětí, nevedly ke ztrátě důvěry vychovatelů a rodičů a ukvapeně nezničily hodnotový systém, který se u dětí tvoří. Výchova v demokratickém duchu a rovnosti od nejútlejšího 
věku vychází z historického vývoje evropské i světové společnosti a jejích potřeb. Všechny společnosti ale nepřijímají další demokratizační postupy, jejichž základem je vždy dobrovolnost a společenský konsenzus, stejným způsobem a podobnou rychlostí. Proto mají společenské diskursy předcházející změnám velký význam pro popularizaci povahy možných změn a pro poznání názorů různých skupin.

V Polsku není tedy existence problematiky genderových stereotypů a jejich důsledků ve veřejném životě zpochybňována, význam těchto otázek ve vzdělávání se uznává a od 80 . let 20. století se objevila řada výzkumů a studií, které svědčí o nerovném přístupu k pohlaví, vzniku diskriminačních mechanismů a posilování stereotypů spojených s pohlavím na různých úrovních vzdělání.

Kategorie gender začala být společensky závažná ve chvíli, kdy Nadace předškolního vzdělávání (Fundacja Edukacji Przedszkolnej) z Wrocławi ${ }^{1}$ začala zakládat malé školky (Předškolní skupiny) v obcích a zaváděla přitom program Genderově rovná školka. Ostré protestní hlasy se ozvaly po dvou letech. Během několika měsíců na přelomu let 2013/2014 prošla společnost rychlokurzem genderové rovnosti ve vzdělávání a její různě intenzivní kritiky. Diskurs je stále živý a před pedagogy a učiteli ve školkách a na základních školách se objevily otázky, na něž musí odpovědět: (1) Patří dítě rodičům, nebo státu? (2) Lze najít nějaký kompromis, rovnováhu mezi pojetím genderu jako vědy a ideologie? (3) Kdo má poslední slovo v rozhodování o osnovách: ministerstvo, rodiče nebo vedení školky? (4) Mohou ve školkách vést kurzy osoby, které nemají pedagogické vzdělání, a jak často? (5) Musí osnovy vždy někdo recenzovat a kdo by to měl být? (6) V jaké šiři a jak rychle by konzervativní společnosti měly uskutečnit doporučení Světové lékařské organizace a Evropské unie v oblasti genderové rovnosti ve vzdělávání? A musí opravdu nekriticky nebo z donucení přijímat navrhované změny v tak citlivé otázce, jakou je pohlaví? Diskurs na toto téma je př́kladem problematické, ambivalentní situace, stavící spoluúčastníky před nutnost volit v okamžiku, kdy mají málo informací. Život člověka ovšem často nutí soukromě nebo pracovně podobné ambivalence řešit (Suchodolski, 1983), a proto je důležité,

1 Viz http://maleprzedszkola.pl/Fundacja [15.03.14]. Nadace uvádí: „Naše projekty realizujeme ve spolupráci s obcemi a místními komunitami. Společně vytváríme nová místa, v nichž se odehrávají kurzy předškolního vzdělávání. Při práci vycházíme ze standardů, podle nichž se spolupráce zakládá na partnerství a společném rozhodování. Dosud jsme navázali spolupráci s 55 obcemi na území 4 vojvodství (Dolnoslezského, Slezského, Lodžského a Mazovského).“ 
aby ani při výchově budoucích učitelů nebyly opomíjeny. Jak píše Wołoszyn: „Dnešní výchova učitelů je - u nás i na světě - zapletená do zdánlivě neřešitelných protikladů. Lze je chápat jako alternativy, ale není možné bez diskuse podporovat jen jednu alternativu" (Wołoszyn, 1998, s. 230).

Náš článek se skládá ze čtyř částí. V první - jako kontext - je představen krátký vývoj názorů na genderovou tematiku v polské odborné literatuře z církevních (konzervativních), liberálních a vědeckých kruhů. Ve druhé jsme se zaměřili na program genderové rovnosti ve školkách, který inspiroval zkoumaný diskurs. Ve třetí potom tento mediální diskurs o zmíněném programu

představujeme. Čtvrtá část se věnuje pro pedagogy důležitým metodologickým otázkám výzkumu genderové problematiky. $\mathrm{V}$ závěru potom shrneme vlastní úvahy spojené jak s popsanými mediálními fakty, tak dualistickým paradigmatem, které načrtáváme v úvodu článku, abychom zdůraznili jeho současnou využitelnost pro pedagogiku.

\section{Problematika genderové rovnosti v polské odborné literatuře}

Gender studies se objevily na západních univerzitách v 70. letech 20. století. $V$ polské vědě a společnosti tato problematika existuje od 80. let. V roce 1982 vyšla pro tento fenomén důležitá kniha Nikt nie rodzi się kobieta (Hołówko, 1982), jejíž základ tvoří výbor textů především amerických autorek na téma ve společenském vědomí silně zakořeněných stereotypů, norem a vzorců spojených s ženskou rolí. Po roce 1989 vznikly další publikace, tvořící základ polské reflexe tématu pohlaví (např. Domański, 1992, 1999; Kwak, 1994; Titkow \& Domański, 1995; Siemieńska, 1997a, 1997b, 1999; Bator, 1998, 1999; Ślęczka, 1999).

Na prahu 21. století se počet publikací, a to především sociologických, značně zvýšil, rozšíril se také vějír témat, jimž se věnují: způsobům konstruování ženskosti v médiích (Desperak, 2013; Zierkiewicz, 2010; Zierkiewicz \& Łysak, 2007), situaci žen na trhu práce, kariérním cestám žen a mužů (Titkow, Duch-Krzysztoszek, \& Budrowska, 2004), sociálním rolím žen (Fuszara, 2013; Siemieńska-Żochowska, 2000; Matland, Montgomery, \& Siemieńska-Żochowska, 2003; Slany, 2013). Byly publikovány práce Kopciewicz z oblasti sociologie výchovy $(2007,2011)$ ajiné (Bator, 2001; Slany, Struzik, \& Wojnicka, 2011; Titkow, 2007). Kromě sociologie se genderu věnovaly i humanitní vědy 
(Janion, 1996; Graff, 2001, 2008; Iwasiów, 2008; Radkiewicz, 2002, 2003, 2004, 2006, 2014).

Na počátku Mens'studies stála kniha pedagoga - Melosika (2002) Kryzys męskości w kulturze współczesnej (více $\mathrm{k}$ tomuto tématu viz Arcimowicz, 2003; Arcimowicz \& Citko, 2009). Existují také publikace věnované problematice queer (Majka-Rostek, 2002, 2008; Kochanowski, 2004, 2009, 2013). Vlna především sociologické odborné literatury z posledních dvou let by vydala na zvláštní práci. Ale už tento přehled dokládá, že se stále rozšiřuje problematika, jíž se autoři věnují, a stále obvyklejší se stává interdisciplinární přistup ke zkoumaným otázkám. Při hodnocení tohoto stavu lze navázat na tezi Witkowského, vyslovenou při jiné př́ležitosti, že imponující oblast témat a diskursů, kterým se sociologie věnuje, ukazuje její humanitní potenciál, dosud neodhalený dokonce i samotnými sociology (Witkowski, 2013, s. 146).

Církev se do diskursu o genderu zapojila poměrně pozdě, dvacet let po změně politického systému. Její zájem ovlivnily teze Benedikta XVI. v roce 2010 a dalších letech, zejména $\mathrm{v}$ období před jeho odstoupením, $\mathrm{v}$ nichž hlásá, že „církev opakuje své velké ,ano' důstojnosti a kráse manželství jako věrného a plodného výrazu spojení muže a ženy. A říká ,ne' takovým filozofiím jako gender." ${ }^{\prime 2}$ Genderová ideologie byla pro Benedikta XVI. jednou z největších výzev církve. Důkazem je i to, že této problematice věnoval více místa než náboženským událostem ve svém proslovu ke kardinálům a biskupům v Římské kurii před Vánoci 2012, když shrnoval nejdůležitější události roku v církvi ${ }^{3}$. Papež František se ovšem tohoto tématu doposud nedotknul a tvrdí, že „kněží by se neměli obsesivně soustředovat na předávání a vnucování mnoha spolu nesouvisejících doktrín. Misijní kázání se musí soustředit na to, co je základní, co probouzí zápal a přitahuje, co rozehřívá srdce“4.

Levicový aktivista S. Sierakowski dává aktivitu církve do souvislosti s jejími vnitřními problémy, které jsou spojeny s aférami špatného fungování majetkové komise nebo př́ípady pedofilie mezi kněžími. Ohrožení genderem je tak

2 Watykan a gender: Sprzeciw Benedykta XVI i milczenie Franciszka (2013), http:// fakty.interia.pl/religia/news-watykan-a-gender-sprzeciw-benedykta-xvi-i-milczeniefrancisz,nId,1080918 [20.05.14].

3 Watykan a gender: Sprzeciw Benedykta XVI i milczenie Franciszka (2013), http://fakty. interia.pl/religia/news-watykan-a-gender-sprzeciw-benedykta-xvi-i-milczeniefrancisz,nId,1080918 [20.05.14].

4 Watykan a gender... [20.05.14]. 
výhodnou mediální pokličkou. Za počátek diskursu se označují výroky biskupa Pieronka během debaty v létě 2012 (Sierakowski, 2014, s. 8-10).

První polský text na téma kulturního pohlaví z církevních kruhů pochází z prvního desetiletí 21. století (např Nagórny \& Pokrywka, 2005; Pokrywka, 2012; Morciniec, 2007, 2008, 2010, 2011; Szafulski, 2008; Jucewicz \& Machinek, 2009; Jucewicz, 2009). Nejnovějším příspěvkem je Dyktatura gender (2014), kolektivní publikace, kde závažnost tématu dokládá výběr autorů (mj. Benedikt XVI., Gabriele Kuby, Waldemar Chrostowski, Krzysztof Fusette, Henryk Hoser, Dariusz Oko).

Pedagogika si tohoto tématu povšimla také pozdě. V pedagogických encyklopediích heslo gender neexistuje, v roce 2005 se však objevila první pedagogická prŕručča Wychowanie a role płciowe, která pro polské pedagogy dodnes zůstává hlavní učebnicí genderu. Vyšla v edici Wyzwania pedagogiki, jejíž druhá ediční řada se zaměřuje na témata z oblasti „současné světové pedagogiky, která jsou v Polsku neznámá nebo málo známá. Tyto otázky zpracovali mladí ambiciózní vědci“ (Pankowska, 2005). Učebnici doplňuje vzdělávací program. Další práce na toto téma se objevila v mnohosvazkové učebnici pedagogiky, již redakčně řídil Śliwerski, ve čtvrtém díle vydaném v roce 2010. Autorkou prríspěvku Pedagogika rodzaju (gender) je Gromkowska-Melosik. Zamýšlí se v něm nad otázkou socializačního patu, vznikajícího ve střetu výchovy a formování pohlavní identity mezi esencialismem a společenským konstruktivismem (Gromkowska-Melosik, 2010, s. 199).

Pro pedagogy může být zajímavé také kolektivní dílo Teoretyczne perspektywy badań nad edukacja rodzajowa (Chomczyńska-Rubacha, 2007), v němž je představena různorodá teoretická i metodologická problematika z pera takových specialistek, jako jsou Chomczyńska-Rubacha, Melosik, Pankowska nebo Tylikowska.

Pedagožka Dobrołowicz se pak ve svých výzkumech zaměřuje na obrazy ženskosti a mužnosti v časopisech pro mládež a obraz školy $(2008,2010,2013)$.

V oblasti pedagogiky čelné místo zaujímá monografie Górnikowské-Zwolak Myśl feministyczna jako nurt rozważań w pedagogice społecznej (2009). Pro pedagogy se díky spojení analýzy a interpretace textů mohou stát důležitými literárněvědné práce Ingy Iwasiów (např. 2008).

Zvláštní oblastí jsou analýzy školních učebnic s ohledem na jejich zobrazení mužů, žen a rodiny (Chomczyńska-Rubacha, 2007, 2011a, 2011b, 2011c; 
2014, s. 269; Zamojska, 2011). Obraz rodiny, který vykreslují, je tradiční, v duchu patriarchální společnosti, kde žena patří do soukromé sféry, zatímco muž do veřejné. Děti potom tento řád a existující stereotypy opakují (Chomczyńska-Rubacha, 2014, s. 269).

Zajímavé je proto sledovat průběh rozvíjejícího se diskursu o kontroverzní vládní učebnici pro prvňáky, kterou v současné době zkoumají odborníci podle prezentace genderové rovnosti ${ }^{5}$.

Tento zběžný a neúplný přehled vybraných publikací dostupných pedagogům měl doložit, že gender není v Polsku kategorií neznámou či jakousi nechtěnou novinkou. Právě naopak, interdisciplinární problematika genderové rovnosti má své teoretické základy, příklady pedagogického výzkumu různých fenoménů i kritické publikace na toto téma, ačkoli ve společnosti je doposud málo známá.

Velmi bohatá odborná literatura polská i zahraniční z posledních dvou let $(2013,2014)$ je tématem pro samostatnou studii.

\section{Podstata a cíle programu Genderově rovná školka}

Připomeňme, že vznik kategorie gender je spojen s opuštěním esencialismu v hlavním proudu humanitních věd. To znamená oddělení toho, co je biologické a neměnné, od toho, co je dané kulturně a v historii se měnilo. Biologické pohlaví (sex) dělí lidská těla podle anatomických vlastností a hormonálních a genetických faktorů na mužská, ženská a intersexuální. Společenské a kulturní pohlaví (gender) označuje soubor významů a chování kulturně spojovaných s ženou a mužem na konkrétním místě a čase. Proměnlivost a mnohost norem a příkladů toho, co je ženské a mužské, zpochybňuje pojetí „Věčné ženskosti a pravého muže“ a vede k závěru, že gender je sociálním konstruktem (Krasuska, 2014, s. 46-49).

Zavedení genderové problematiky do předškolního vzdělávání, při zohlednění zásady poznávací decentrace, mělo za cíl, jak vysvětluje Chomczyńska-Rubacha, rozšírit schopnost hodnotit jiné tak, že jsme schopni zaujmout vůči našemu já vnější úhel pohledu na jejich osobnost. Chlapec, který občas chodí na podpatcích, si může představit, co cítí žena, když v takových botách chodí, ale nestane se kvůli tomu ženou (Chomczyńska-Rubacha, 2014, s. 275).

5 Viz http://wpolityce.pl/lifestyle/190919-rodzice-protestuja-przeciwko-promocji-ideologiigender-w-darmowym-podreczniku-dla-pierwszoklasistow, [22.05.14]. 
Genderově rovná školka je první program (či spíše příručka) v Polsku, který se věnuje otázkám rovnosti pohlaví ve výchově dětí. Vychází ze zkušeností švédských školek. Na svém webu ho v roce 2011 publikovala Nadace předškolního vzdělávání, organizující malá centra, spolu s jinými dokumenty o své činnosti, týkajícími se této problematiky6.

V př́ručce Polityka równościowa w programach przedszkolnych (2011) její autorky Dzierzgowska, Piotrowska a Rutkowska analyzovaly vybrané výchovné předškolní programy $\mathrm{z}$ pohledu realizace genderové rovnosti ${ }^{7}$. Ve shrnutí těchto analýz formulovaly závěr, že politika genderové rovnosti v nich neexistuje - ani na úrovni obecných východisek a strategií, ani v jednotlivých prvcích, jako jsou návrhy her, cvičení a úkoly zadávané dětem. Stejně tak učitelé a učitelky ve školkách nemají k dispozici žádná doporučení nebo pomoc, důsledkem chybějící genderové perspektivy ve veřejných vzdělávacích aktivitách je přijetí „univerzalistické“ perspektivy, v níž nejsou občané rozlišováni podle pohlaví, a následně je nemožné identifikovat a popsat jejich rozdílné potřeby a očekávání.

Další př́ručkou těch samých specialistek je Poradnik dla nauczycieli. Jak stosować zasadę równego traktowania kobiet i mężczyzn ${ }^{8}$.

Ale hlavním dokumentem, který nás zajímá, je program Równościowe Przedszkole. - Jak uczynić wychowanie przedszkolne wrażliwym na płeć, jehož autorkami jsou opět výše zmíněné odbornice (Dzierzgowska, Piotrowska, \& Rutkowska, 2011). V úvodu čtenáře informují, že jimi navrhovaný program předškolní výchovy zohledňující perspektivu pohlaví není typickým návrhem a není možné podle něj, krok za krokem, vést děti celý rok. Autorky se domnívají, že genderově rovná perspektiva a pedagogika by se měly stát jedním z důležitých aspektů každého programu předškolní výchovy, protože existující programy jsou sice dobré a zajímavé, ale tento přístup v nich chybí. Jedním z jejich úkolů je tedy přinášet vzory a návody, jak podobné vzdělávání vést, jak se vyhýbat genderovým stereotypům, jaké myšlenky posilovat a jaké oslabovat. „Domníváme se, že genderově rovná školka by měla být skutečným rájem pro děti, $v$ němž se mohou cítit bezpečně a akceptované v tom, jaké jsou a co rády dělají“ (Dzierzgowska et al., 2011s. 15).

http://maleprzedszkola.pl/Pobieralnia [20.03.14].

Viz http://maleprzedszkola.pl/Pobieralnia [20.03.14].

Dzierzgowska, Piotrowska, \& Rutkowska, http://maleprzedszkola.pl/ Pobieralnia [20.03.14]. 
Čtenáře však znepokojilo, že autorka zdůrazňuje dětskou sexualitu:

Zvláštním problémem je úplné ignorování fenoménu dětského zájmu o tělesno ve školních osnovách. Děti jsou nejen na jazykové rovině chápány jako bytosti zcela asexuální. Do očí bijící je zamlčování jak problémů spojených se sexuálním obtěžováním, tak fenoménu dětské tělesnosti. $\mathrm{V}$ osnovách se mluví o výchově ke zdraví a také o tom, že se mají děti učit, jak se vyhnout různým nebezpečím. (Dzierzgowska et al., 2011, s. 29)

Veřejnost byla pobouřena i poznámkou, že rodiče nemají být zapojeni do vzdělávání svých dětí, pokud se nedokáží oprostit od stereotypů.

Program byl doplněn př́klady výukových scénářů s návrhy, jak dekódovat obsah oblíbených pohádek, legend a tvorby pro děti, hrami (s převlékáním chlapců do ženského oblečení, což bylo rovněž kritizováno) a slovníčkem. Realizován byl v 86 školkách, které nadace vede od roku 2011.

Četba zmíněného programu nebudí negativní emoce, program se zdá být návrhem rozumným a vyváženým. Vše ale záleží na způsobu, jakým učitelky a učitelé využijí představené návrhy, citlivém přístupu k očekáváním společnosti a atmosféře vytvářené ve školce a lokální komunitě kolem programu.

\section{Diskurs v polských médiích o programu Genderově rovná školka}

Dualistické paradigma, o němž se zmiňujeme, je založeno na metodologické perspektivě formulování a rozpoznávání složitosti a paradoxní podstaty jevů, které jsou obvykle nahlíženy jednostranně a omezeně (Witkowski, 2013, s. 147). Podle našeho názoru jeho využitelnost spočívá v přístupu nepolarizujícím fakta a jejich dynamickém chápání, zůstávají tak v napětí a oscilují mezi krajnostmi. Tato perspektiva je alternativou ke známým metodám výzkumu diskursu nebo je doplňuje. Tento přístup k diskursu, chápanému nejdříve jako mediální souboj dvou protichůdných sil, umožňuje nasměrovat pozornost vědce na individuální rozdíly mezi výroky, jejich jazyky a úrovní emocionální angažovanosti autorů a lokalizuje je v různé vzdálenosti od extrémů. Vzniká tak „mapa“ nebo „vějiŕr“" názorů přítomných v diskursu a zároveň se zlepšuje pochopení zkoumaného jevu. Dualistické paradigma totiž vychází z citlivosti a reflexe všech úhlů pohledu, které bývají omezeny, redukují a vedou tak k jednostrannosti vědeckého zkoumání (Witkowski, 2013, s. 719). Naše studie by měla být malým pokusem o takovou snahu. 
Mediální diskurs o genderově rovné školce měl a má řadu účastníků, soustředíme se tedy jen na vybrané př́klady, zmiňovat nebudeme zkrácené nebo přetištěné zprávy na lokálních portálech. V květnu 2013 katolický měsíčník portál wSumie.pl informoval:

Nadace předškolního vzdělávání dostala na svou činnost 15 milionů zlotých od Evropské unie, ale její šéf se musel zavázat k propagaci genderu ve školkách. Projekt potichu probíhá tři roky. Proč o něm víme tak málo? Před dvěma lety vzniklo 12 genderově rovných školek ve Slezském vojvodství. Šéf Nadace předškolního vzdělávání z Wrocławi Tadeusz Szmigiel za dotace EU otevřel pobočky mj. v obcích Rudziniec, Siewierz, Żarki, Olsztyn, Włodowice a Niegowa. Školky už nefungují. ${ }^{9}$

Mezi řádky sugeruje čtenářům, že záměrem pracovníků nadace bylo vydělat si šířením ideologie, která je rodičům dětí cizí. Informaci ochotně opakovaly další portály. Motiv peněz, jež lidé popularizující gender dostávají v podobě grantů nebo diet, se objevil ještě několikrát.

Po opakujících se obviněních z ideologizace předškolní výchovy a sexualizace dětí byl nadační tým nucen bránit se vydáním prohlášení. $V$ prohlášení ze 4. listopadu 2013 přesvědčoval veřejnost:

V našich školkách se soustřed'ujeme na vyrovnání vzdělávacích př́iležitostí dětí, které by se bez naší podpory neměly šanci zapojit do předškolních programů. Nadace je světonázorově neutrální organizací. Neprosazujeme žádnou ideologii. Za výchovu svých dětí jsou zodpovědní rodiče a jen oni mohou rozhodovat o tom, jaké hodnoty jim chtějí vštěpovat. Předškolní centra, která otvíráme, vznikají díky prostředkům získaným z unijních fondů a ve spolupráci s obcemi. Každý projekt spolufinancovaný Evropskou unií musí obsahovat prvky spojené s podporou rovných př́ležitostí žen a mužů. [...] Toto pravidlo je norma vyžadovaná ve všech projektech realizovaných v celém Polsku. Ani naše projekty nejsou výjimkou. Ve školce se jednou za měsíc konají kurzy, jejichž cílem je podpořit rovné šance. [...] Rodiče, kteří se do projektu zapojují, jsou podrobně informováni o tom, že se ve školce takové kurzy budou konat a často se jich sami účastní. ${ }^{10}$

V dalším prohlášení z 5. listopadu 2013, o příručce pro učitele, nadace informuje:

9 Viz http://wpolityce.pl/spoleczenstwo/74500-niszcza-psychike-dzieci-dla-dotacji [20.03.14]

10 Viz Oświadczenie Fundacji edukacji Przedszkolnej http://maleprzedszkola.pl/Pobieralnia [13.03.14]. 
Poradnik dla nauczycieli - Jak stosować zasadę równego traktowania kobiet i mężczyzn zveřejněný na naší internetové stránce není výukovým programem. Je to pomůcka pro učitele, jejímž cílem je podpora př́ípravy výukových scénářů překonávajících stereotypní vnímání mužských a ženských rolí. ${ }^{11}$

Prohlášení však emoce spojené s programem neuklidnilo. Odbornou recenzi programu připravil Tým prvotního vzdělávání Polské akademie věd (Zespół Edukacji Początkowej Polskiej Akademii Nauk - PAN) až v lednu 2014. Lze se domnívat, že „pod tlakem“ situace a vypjatosti diskuse. Dočteme se v ní mj., že program předložený k hodnocení není možné kvalifikovat jako program předškolního vzdělávání, protože podle požadavků obsažených v příslušných právních dokumentech musí být program přizpůsobený potřebám a možnostem dětí, pro něž je určen, ale tento dokument je určen pro dospělé. Navíc $\mathrm{v}$ něm chybí detailní cíle vzdělání a výchovy, které by reagovaly na úkoly, stojící před předškolní výchovou, a děti silně instrumentalizuje ${ }^{12}$. Fragmenty hodnocení ilustrují, že názorově vlivní vědečtí pracovníci se svým vstupem do diskuse pokoušeli racionalizovat jak výtky k programu, tak jeho smysluplnost ve vzdělávacím prostoru, a vzniklé společenské dilema vyřešit.

10. ledna 2014 byl ovšem v médiích otištěn otevřený dopis premiéru Tuskovi ve věci obrany gender studies, jehož signatáři mimo jiné píší, že v Polsku je již několik měsíců vedena - v médiích s oblibou exponovaná - kampaň proti „genderové ideologii“ a že jejím posledním kulminačním bodem byl v kostelích předčítaný Dopis polského episkopátu na Neděli Svaté rodiny, vytvářející obraz nepřítele odpovědného za ničení rodiny, morální úpadek a zejména jev nazývaný „sexualizací dětí“. Autoři zdůrazňují, že jazyk kampaně útočící na "genderovou ideologii“ charakterizuje nenávistný tón (hate speech). Obviňuje je také ze všech negativních společenských procesů, až po podezření z trestných činů jako navádění k pedofilii. A klade dramatické otázky: Co se stane, až vědci, odborníci a společenští aktivisté svoji práci vyhodnotí jako př́liš nebezpečnou nebo odporující státnímu zájmu a přestanou ji dělat? Bude Polsko schopné splnit své mezinárodní závazky a podílet se na programech Evropské unie? ${ }^{13}$

11 Viz http://maleprzedszkola.pl/Pobieralnia [13.03.14].

12 Bałachowicz J., Opinia programu autorstwa Pań Anny Dzierzgowskiej, Joanny Piotrowskiej, Ewy Rutkowskiej pt. Równościowe przedszkole. Jak uczynić wychowanie przedszkolne wrażliwym na płeć, http://www.psychologia.net.pl/serwis.php?level=1303 [fragmenty publikovány s komentářem 20.01.14].

13 Viz http://wyborcza.pl/1,95892,15248524 Nie_ma_innej__ideologii_gender_niz_ta_mowia ca_o.html\#ixzz2w4D10faO [15.03.14]. 
Jazyk tohoto dopisu ovšem také svědčí o emocionálním přístupu k diskursu. Není to klidné odmítnutí obvinění druhé strany, vysvětlení pochybností a uklidnění nálad, ale pokus a vydírání a útok.

29. ledna 2014 neziskové organizace podporující genderově rovné vzdělávání, překvapené seznamem výtek k programu Genderově rovná školka, zaslaly otevřený dopis na obranu kritizovaného programu vedoucímu Výboru humanitních věd PAN (Komitet Nauk Społecznych PAN), profesorovi Śliwerskému, zpochybňovaly oprávněnost hodnocení a dokazovaly přitom, že se jeho autoři při evaluaci tohoto programu řídí nesprávnými kritérii.

Autoři jim vyčítají manipulaci a nepoctivost, protože recenze diskredituje materiál určený dospělým, její metodologie je chybná a vede k neopodstatněným závěrům. Navíc připomínají, že zavádění témat rovnosti a anti-diskriminace do systému formální výuky je v souladu s vyhláškou o pedagogické kontrole. Ptají se také na to, jakou činnost Výbor humanitních věd PAN vyvíjí, aby co nejvíce rozšíríl odpovídající materiály podporující citlivost učitelů/ učitelek $\mathrm{k}$ výše zmíněné problematice. ${ }^{14}$ (Dokument podepsalo 41 neziskových organizací. Jeho tón je silně agresivní, dominuje povýšenost, neomylnost a jednostranné přesvědčení o vlastní pravdě, bez zohledňování nálad ve společnosti. Śliwerski odpovídá rovněž velmi emotivně:

Zatahování neziskových organizací a odborové organizace do tohoto manévru nás staví před otázku, zda jejich šéfové vědí, pod čím se podepsali. Připojili totiž podpis pod to, že je možné vnucovat učitelům publikaci s logem veřejné instituce bez jakékoliv recenze.[...] Sám jsem se v různých rolích (i jako hodnotící) účastnil realizace několika vzdělávacích programů z prostředků EU, ale nebylo přípustné, aby tzv. finální produkt, který je adresovaný příjemcům, nebyl vůbec hodnocen! [...] Domnívá se paní M. Rawłuszko, že když shromáždí třeba i 200 signatářu svého dopisu, získá právo cenzurovat vědecké názory publicistickým stylem? ${ }^{15}$

Další otevřený dopis se dostal do rukou prof. Śliwerského 14. února 2014 a jeho autorkami byly významné odbornice z několika univerzit: prof. dr. hab. Maria Czerepaniak-Walczak, prof. dr. hab. Mariola Chomczyńska-Rubacha, dr. hab. Dorota Pankowska a dr. Iwona Chmura-Rutkowska. V dopise se dočteme mj.:

14 Vizhttp://www.krytykapolityczna.pl/artykuly/kraj/20140129/rownosciowe-przedszkolemusi-zostac-list-otwarty [13.03.14].

15 http://sliwerski-pedagog.blogspot.com/2014/01/list-otwarty-w-sprawie-opinii.html [13.02.14]. 
Již více než dvacet let jsou v Polsku, rovněž v oblasti pedagogiky, realizovány výzkumy a vědecké analýzy o společenském a kulturním pohlaví. Výsledky těchto výzkumů prezentujeme v četných publikacích, které do této doby nebudily větší zájem neakademických kruhů, což znesnadňovalo popularizaci genderové problematiky jak ve společenském povědomí, tak v pedagogické praxi. I proto [...] je stále viditelná diskriminace na základě pohlaví v řadě oblastí veřejného života. Dosažení plné rovnoprávnosti žen a mužů vyžaduje změnu společenského vědomí, ta je pak možná jen díky vzdělávání na všech úrovních výchovy - od školek po univerzity. ${ }^{16}$

V další části dopisu signatářky upozorňují na to, že plnění těchto závazků ve vzdělávací praxi je komplikovaný proces vycházející ze spolupráce vědců, učitelo̊, rodičů a zástupců místních a osvětových samospráv. Jako každá změna vyžaduje, aby byly překonány stereotypy a vytvořena pozitivní atmosféra pro realizaci demokratizačních aktivit. Tvrdí, že ideologizace pojmu gender, mj. přisuzováním témat tomuto pojmu, která nejsou jeho součástí, jako sexuální výchova, homosexualismus, transsexualismus, pornografie a pedofilie, je nejen intelektuální, ale i morální zneužití této kategorie. Protestují proti přivlastňování si veřejného diskursu v této otázce a ignorování vědeckých výsledků, dezinformování a tvorbě atmosféry strachu. A dodávají:

Dětem neubližují vědci zaměřující se na společenské a kulturní pohlaví, autorky vzdělávacích programů nebo učitelky a učitelé, kteří vedou anti-diskriminační kurzy, ale ti, kteří se blokováním těchto aktivit pokoušejí o návrat patriarchálního společenského řádu z 19. století. Výchova upevňující anachronické stereotypy o pohlaví stojí v protikladu k demokratickým principům a axiologickým základům polského vzdělávacího systému. ${ }^{17}$

Dopis je psán ve věcném tónu, týká se obecnějších otázek než pouze předškolního vzdělávacího programu, ale i v tomto dokumentu chybí pochopení pro argumenty druhé strany a znepokojení, které může v konzervativní společnosti nová problematika budit. Netýká se přeci už jen rovnoprávnosti žen a mužů, na což signatáři zapomínají. Chybí pokus vysvětlit, odkud pocházejí výhrady a znepokojení a o jakých konkrétních axiologických základech polského vzdělávacího systému je řeč. Zprávy v médiích z března 2014 se věnují udělování certifikátu církevních nadací školám, které se chtějí „osvobodit od genderu“:

16 Viz http://sliwerski-pedagog.blogspot.com/ [14.02.14].

17 Tamtéž. 
Učitelé protestují: Škola se má osvobodit ne od genderu, ale od ideologických střetů. Ministerstvo školství požaduje vysvětlení mazovského Kuratoria osvěty. $\mathrm{Z}$ jakých peněz chtějí školy financovat církevní certifikáty? ptá se ministryně Joanna Kluzik-Rostkowska. ${ }^{18}$

Okamžité vysvětlení této otázky požaduje také Sławomir Broniarz, předseda Svazu polských učitelů, překvapený prŕístupem ředitelů škol. Zapomněli snad, že škola má být světská?

Náš svaz již několik měsíců apeluje, aby se školy osvobodily od ideologických sporů. A zavádění podobných certifikátů je právě takové ideologizování. [...] Musí skončit stigmatizování učitelů, kteří chtějí učit o rovnosti pohlaví, stejně jako vyvolávání konfliktů a nepokojů ve školách. Církev by tomu neměla napomáhat. ${ }^{19}$

Certifikáty brání autorka jiné publikace:

Zdá se mi, že předseda svazu si plete pojem světskost s úctou k polské ústavě. Celý program, propagovaný Nadací Centrum podpory iniciativ pro život a rodinu (Fundacja Centrum Wspierania Inicjatyw dla Życia i Rodziny), je založen na článcích ústavy, které jednoznačně přiznávají právo na výchovu dětí v hodnotách vycházejících z přesvědčení jejich rodičů. ${ }^{20}$

Chybí rovněž diskuse o obsahu knihy Kuby (2014) vydané nedávno v Polsku, v níž představuje nejdříve profily pionýrů genderismu a zdůrazňuje ty části jejich života a díla, které se týkají sexu a sexuality, představuje studentské bouře roku 1968, iniciující právní deregulaci lidské sexuality, dotýká se otázky feminismu a genderové teorie Judith Butlerové nebo problému globalizace sexuální revoluce, způsobené mj. vznikem Všeobecné deklarace lidských práv. Nakonec se dostává k jevům ležícím v základu diskursů otřásajících Polskem v posledních měsících: Jakartským principům, politice Evropské unie a zavádění základů gender do politiky, zákonodárství, vědy, škol a školek.

18 Viz http://wyborcza.pl/1,75478,15685743, Szkoly_wolne_od_gender__koscieln_fundacj_ sprzedaje.html?utm_source=facebook.com\&utm_medium=SM\&utm_campaign=FB_Gazeta_ Wyborcza\#ixzz2x3qcBRkP [26.03.14].

19 http://www.znp.edu.pl/element/1869/Oswiadczenie_ZNP_w_sprawie_edukacji_ rownosciowej [26.03.14].

Již v prosinci 2013 vydalo ZNP oficiální vyjádření na obranu učitelky z jedné školky, v němž se píše: „ZNP vyjadřuje rozhodný nesouhlas s agresivitou zaměřenou proti učitelkám a učitelům, kteří realizují genderově rovné vzdělávání (zvané také rodové nebo genderové vzdělávání).

20 K. Kawlewska, Dyrektorzy szkół przeciw gender!, http://wsumie.pl/spoleczenstwo/103072dyrektorzy-szkol-przeciw-gender [26.03.14]. 
Díky podobným publikacím a mediálním diskursům genderová problematika ukazuje společnosti různé tváře a nutí $\mathrm{k}$ zamyšlení nad vlastními postoji $\mathrm{k}$ tomuto tématu. Prozatím diskurs o předškolním programu ukázal, že jsme uvězněni mezi Skyllou konzervatismu a Charybdou liberalismu a nemůžeme počítat s racionálním právním a organizačním řešením. Protože diskurs je stále živý, chápeme sebraný materiál jako zprávu o sledu společenských a mediálních faktů s ambivalentním charakterem a pokus o pohled na ně prizmatem dualistického paradigmatu.

\section{Metodologické aspekty výzkumu rodového vzdělávání ve školce}

Spolu se společenským diskursem se před učiteli a pedagogy otvírá široké pole vědeckého bádání. Zatímco akademické prostředí již má s tímto fenoménem díky gender studies zkušenosti, praktici se zatím nedokáží v nové situaci zorientovat, ačkoli některé z již existujících publikací mohou být dobrým př́íkladem odpovídajícího výzkumného procesu (Chomczyńska-Rubacha, 2007; Kamińska-Berezowska \& Klimczak-Ziółek, 2007, s. 167).

Výzkumným polem a cílem se může stát v první řadě vlastní praxe: metodika, její kontext, kvalita a efekty. K využití se zde nabízí kvalitativní strategie akčního výzkumu, upravená pro pedagogiku a didaktiku (Červinková \& Gołębniak, 2010, 2013; Kaliszewska, 2011).

Vědecky hodnotné se stává zkoumání mediálního diskursu o genderové problematice (březen, 2011), které nás seznamuje s objevujícími se tendencemi, obrazem školky, školy a jejích problémů a přípravou na úkol zavádět tuto novou problematiku do vzdělávání v daných institucích. V Polsku jsou metody výzkumu diskursu již známé (např. van Dijk, 2006; Derrida, 2009).

Mediální diskurs je pouze jednou z variant možných diskursů, které zkoumá řada disciplín. Diskurs je předmětem zájmu jazykovědy, lingvistiky, psychologie, filozofie, sociologie a pedagogiky a využití a oblast chápání diskursu záleží na konkrétním teoretickém paradigmatu daného oboru nebo jiných teoretických kontextů (Kawka, 2012, s. 21).

Podle názoru pozitivistů a zástupců empirismu slouží diskursy chápané jako „noetické rámy (schémata)" $\mathrm{k}$ institucionálnímu utváření obecně opakovaných představ a smyslů. Analýza diskursu tedy slouží k utvrzování stupně úspěšnosti podobných činností. Zástupci realistických koncepcí diskursu se 
pak zaměřují spíše na noetické aspekty teorie a analýzy, diskursy jsou potom „specifickými předměty“ s různými vlastnostmi a cílem jejich analýzy je odhalení „pojmových elizí a omylů, s jejichž pomocí jazyk vládne“ (Horwath, 2008, s. 14-16).

Marxisté oproti tomu kladou navíc důraz na analýzu diskursu střetů ve sféře hospodářské produkce a reprodukce, diskurs pak vnímají jako ideologický systém významů (Horwath, 2008, s. 16.).

Při rozvíjení tzv. kritické analýzy diskursu Norman Fairclough a jeho škola integrovali řadu sociologických a filozofických př́stupů a zdůrazňovali přitom, že význam a porozumění hrají klíčovou roli ve vysvětlování sociálního světa. Cílem kritické analýzy diskursu je odhalování mechanismů, s jejichž pomocí jsou jazyk a významy využívané mocí, pro oklamání a zneužívání ovládaných (více na toto téma Fairclough, 2003; Fairclough \& Duszak, 2008; Horwath, 2008, s. 17).

Jak dodává Kawka (2012, s. 22), pojem kritické analýzy diskursu dnes nahrazuje pojetí kritické analýzy o diskursu a je tak zdůrazněna interdisciplinarita metody.

Derrida i Foucault (poststrukturalisté) navrhují obecnější koncepci diskursu. „Prohlubují hermeneutický zájem o procesy společenské tvorby smyslu, a zároveň konstatují, že společenské struktury jsou ve své podstatě neřešitelnými, neuzavřenými a indeterministickými systémy významů“ (Kawka, 2012, s. 23; srov. Horwath, 2008, s. 17).

Prezentovaný mediální diskurs o programu Genderově rovná školka může tedy být předmětem kritické analýzy diskursu nebo předmětem hermeneutického zkoumání, a to $\mathrm{v}$ závislosti na cíli výzkumu. Mezi paradigmaty přítomnými v sociálních vědách lze vybrat vědeckou strategii založenou na interpretativním a nejednolitém paradigmatu, které bude navazovat na symbolický interakcionismus, hermeneutiku, sociologii Maxe Webera, konstruktivismus, etnometodologii a fenomenologii (Dobrołowicz, 2013, s. 101).

V odborné literatuře je zároveň zdůrazňována zásadní role diskursu ve formování sociální reality a lidské identity. Diskursy spoluvytvářejí objekty, o nichž mluví, a skrývají přitom vlastní zásahy (Melosik, 1994, s. 201).

Př́nosnou a zajímavou oblastí výzkumu se stává povědomí, názory a postoje učitelů a rodičů $\mathrm{k}$ genderové tematice. Jejich poznání a pochopení může po- 
moci v tvorbě výukových programů pro učitele a žáky nebo vést ke zvýšení kvality spolupráce jednotlivých pracovišt' s rodiči a vychovateli žáků. K těmto cílům se většinou využívají metody sondáže. V Polsku je také známá a používaná specifická metodologie genderového výzkumu, např. školních učebnic či tzv. rodová analýza (Leach, 2003, s. 102-123).

Genderové problematice se nelze v pedagogice vyhnout, ale není možné nechat ji napospas ideologické manipulaci. Proto je nezbytné učitele a pedagogy na tuto oblast života a výchovy člověka upozornit zavedením genderové problematiky do akademické pedagogiky na stálo, zdokonalováním metodologie jejího pedagogického výzkumu a př́pravou a povzbuzováním pedagogů $\mathrm{k}$ volbě těchto témat $\mathrm{v}$ diplomových pracích a $\mathrm{v}$ účasti ve společenských diskursech na toto téma.

\section{Závěr}

Ve shrnutí bych se chtěla zaměřit na dvě důležité otázky. První z nich je hodnocení vědeckého a didaktického přínosu dualistického paradigmatu. Druhá myšlenka se týká specifika genderové problematiky, přítomné ve společenských diskursech.

Dualistické paradigma prozatím nemá metodologickou interpretaci na praktické úrovni ani mnoho př́kladů jejího užití. Je to autorský návrh Witkowského, (1994a, 1994b, 1995, 1998, 2001), který má šanci zanedlouho obohatit metodologii pedagogického výzkumu. Osobní zkušenosti tohoto autora s využitím této vědecké perspektivy ukazují její potenciál a inspirační hodnoty i pro akademickou didaktiku. Navíc, jak píše Witkowski:

Spor o ambivalenci nebo dualismus se neomezuje na debatu o kvalitě akademického diskursu v tom nebo onom oboru. Je to totiž otázka naší sociální citlivosti a morální představivosti a schopnosti uvědomit si míru složitosti situací spojených s našimi činy a jejich důsledky. (Witkowski, 2013, s. 711)

Diskurs o předškolním programu se vyznačuje silně polarizovanými postoji, a proto není možné (prozatím) získat společný pohled na otázku zavedení genderově rovného vzdělávání ve školkách a jeho rozsah.

Při pohledu na veřejný diskurs o genderově rovných školkách si lze povšimnout, že je výhodným nástrojem pro vedení sporů a bojů mezi často krajními ideologiemi. Gender chápe sám sebe jako další lék na zkostnatělost tradič- 
ních feministických doktrín, které se pokoušejí hlouběji zakořenit v současné liberální skutečnosti. Je to také nová výzva pro mladou generaci, pokus vyjít naproti novým problémům. Společnost, do níž započítáváme také rodiče předškoláků a učitele, pak často není schopna s celým mediálním diskursem držet krok, zvláště proto, že je zveličený a „nafouknutý“ novináři a zbytečně bulvarizovaný. Nezapojuje se do tohoto diskursu hlavně proto, že má malé povědomí o jeho obsahu a pak nekriticky entuziasticky nebo hystericky přijímá názory a argumenty jedné nebo druhé strany. Teprve čas ukáže, jak tyto liberální myšlenky, jakou rychlostí a $\mathrm{v}$ jaké podobě přijme $\mathrm{z}$ větší části konzervativní a katolická společnost, když jejich současná adaptace probíhá tak špatně a pomalu. Je to zároveň další etapa na cestě ke svobodě a rovnosti. Ale každá nová myšlenka, pokud je pro společnost kontroverzní, musí podle mého názoru nejprve získat širší společenské uznání, než se dostane do škol a školek.

Proto je důležitým úkolem vědeckých kruhů nejen tuto oblast nadále zkoumat, ale také popularizovat povědomí o kulturním pohlaví. Není totiž dobré, když se široká veřejnost s tímto pojmem seznamuje jen prostřednictvím velmi emocionálních a ve svých postojích silně polarizovaných mediálních diskursů. Nutné je rovněž přiblížit tuto tematiku studentům pedagogiky a dalších učitelských oborů.

\section{Literatura}

Andrukowicz,W.(2006). Szlachetny pożytek. Ofilozoficznejpedagogice Bronisława Trentowskiego. Szczecin: Naukowe USz.

Arcimowicz K. (2003). Obraz mężczyzny w polskich mediach: prawda, fałsz, stereotyp. Gdańsk: Gdańskie Wydawnictwo Psychologiczne.

Arcimowicz, K., \& Citko, K. (Eds.). (2009). Wizerunki mężczyzn i kobiet w najnowszym filmie europejskim. Białystok: Wyd. Trans Humana.

Bator, J. (1998). Wizerunek kobiety w reklamie telewizyjnej. Warszawa: ISP.

Bator, J. (1999). Wizerunek kobiety w polskiej debacie politycznej: perspektywa frministyczna. Warszawa: ISP.

Bator, J. (2001). Feminizm, postmodernizm, psychoanaliza: filozoficzne dylematy feministek „drugiej fali”. Gdańsk: Słowo Obraz Terytoria.

Červinková, H. \& Gołębniak, B. D. (Eds.). (2010). Badania w działaniu. Pedagogika i antropologia zaangażowane. Wrocław: Naukowe Dolnośląskiej Szkoły Wyższej.

Červinková, H. \& Gołębniak, B. D. (Eds.). (2013). Edukacyjne badania w działaniu. Warszawa: Scholar.

Chomczyńska-Rubacha, M. (Ed.). (2007). Teoretyczne perspektywy badań nad edukacja rodzajową. Łódź: Wyższa Szkoła Humanistyczno-Ekonomiczna w Łodzi. 
Chomczyńska-Rubacha, M. (2011a). Płeć i szkoła: od edukacji rodzajowej do pedagogiki rodzaju. Warszawa: Wyd. Nauk. PWN.

Chomczyńska-Rubacha, M. (2011b). Podręcznik jako przedmiot badań genderowych. In M. Chomczyńska-Rubacha (Ed.), Podręczniki i poradniki. Konteksty. Dyskursy. Perspektywy, Kraków: Oficyna Impuls.

Chomczyńska-Rubacha, M. (Ed). (2011c). Podręczniki i poradniki. Kraków: Oficyna Impuls.

Chomczyńska-Rubacha, M. (2014). Możliwa jest szkoła walcząca o równość (S Mariolou Chomczyńską-Rubachou hovoří Monika Szlosek). In Gender. Przewodnik krytyki politycznej. Warszawa: Wydawnictwo Krytyki Politycznej.

Derrida, J. (2009). Struktura, znak i gra w dyskursie nauk humanistycznych. In L. Rasiński (Ed.), Jezzyk, dyskurs, społeczeństwo. Warszawa: Wyd. Naukowe PWN.

Desperak, I. (2013). Płeć zmiany: zjawisko transformacji w Polsce z perspektywy gender. Łódź: UŁ. van Dijk, T. A. (2006). Badania nad dyskursem. In A. Jasińska-Kania (Ed.), Współczesne teorie socjologiczne, t. II (s. 1020-1046). Warszawa: Wyd. Scholar.

Dobrołowicz, J. (2008). Przygotowanie do „bycia kobietą”. Strategie wybranych czasopism dla dziewcząt. Rekonesans. In D. Ruszkiewicz \& S. Cudak (Eds.), Kobieta i jej wielopostaciowość we współczesnym świecie (s. 145-153). Kielce: Uniwersytetu HumanistycznoPrzyrodniczego Jana Kochanowskiego.

Dobrołowicz, J. (2010). Jaki jest chłopak? Dyskurs męskości w piśmie dla trzynastolatek. Kielce: Uniwersytetu Humanistyczno-Przyrodniczego Jana Kochanowskiego.

Dobrołowicz, J. (2013). Obraz edukacji w polskim dyskursie prasowym. Kraków: Oficyna Impuls.

Domański, H. (1992). Zadowolony niewolnik?: studium o nierównościach między mężczyznami $i$ kobietami w Polsce. Warszawa: IfiS PAN.

Domański, H. (1999). Zadowolony niewolnik idzie do pracy: postawy wobec aktywności zawodowej kobiet w 23 krajach. Warszawa: IfiS PAN.

Dudzikowa, M. (1998). Autorytet (nauczyciela) jako problem pedagogiczny z perspektywy końca wieku. In A. Siemak-Tylikowa (Ed.), Edukacja nauczycielska w perspektywie wymagań zmieniającego się świata. Warszawa: Akademickie Żak.

Dyktatura Gender. (2014). Luty: Biały Kruk.

Dzierzgowska, A., Piotrowska, J., \& Rutkowska, E. (2011). Równościowe Przedszkole - Jak uczynić wychowanie przedszkolne wrażliwym na płeć. Fundacja Edukacji Przedszkolnej.

Elias, N. (2003). Zaangażowanie i neutralność. Warszawa: Wyd. Nauk. PWN.

Fairclough, N. (2003). Analysing discourse: Textual analysis for social research. London: Routledge.

Fairclough, N., \& Duszak, A. (2008). Wstęp. Krytyczna analiza dyskursu - nowy obszar badawczy dla lingwistyki i nauk społecznych. In A. Duszak \& N. Fairclough (Eds.), Krytyczna analiza dyskursu. Interdyscyplinarne podejście do komunikacji społecznej (s. 7-29). Kraków: Universitas.

Fuszara, M. (2013). Kobiety, wybory, polityka. Warszawa: ISP.

Gnitecki, J. (1994). Zarys pedagogiki ogólnej. Poznań: Wyd. Nauk. PTP.

Górnikowska-Zwolak, E. (2009). Myśl feministyczna jako nurt rozważań w pedagogice społecznej. Mysłowice: Wyd. Górnośląskiej Wyższej Szkoły Pedagogicznej im. Kardynała Augusta Hlonda.

Graff, A. (2001). Świat bez kobiet: płeć w polskim życiu publicznym. Warszawa: W.A.B.

Graff, A. (2008). Rykoszetem: rzecz o płci, seksualności i narodzie. Warszawa: W.A.B. 
Gromkowska-Melosik, A. (2010). Pedagogika rodzaju (gender). In B. Śliwerski (Ed.), Pedagogika: subdyscypliny i dziedziny wiedzy o edukacji (s. 199-207). Gdańsk: GWP Pedagogika.

Hołówko, T. (Ed.). (1982). Nikt nie rodzi się kobietą. Warszawa: Czytelnik.

Horwath, D. (2008). Dyskurs. Tłum. A. Gąsior-Niemiec. Warszawa: Oficyna Naukowa.

Iwasiów, I. (2008). Gender dla średnio zaawansowanych. Wykłady szczecińskie. Warszawa: W.A.B.

Janion, M. (1996). Kobiety i duch inności. Warszawa: Sic!

Jaworska-Witkowska, M. (2009). Ku kulturowej koncepcji pedagogiki. Kraków: Oficyna Impuls.

Jucewicz, A. (2009). Katolicka teologia ciała płciowego wobec idei „płci kulturowej. In A. Jucewicz \& M. Machinek (Eds.), Idea gender jako wyzwanie dla teologii (s. 67-80). Olsztyn: Wydawnictwo Hosianum.

Jucewicz, A., \& Machinek, M. (Eds.). (2009). Idea gender jako wyzwanie dla teologii. Olsztyn: Wydawnictwo Hosianum.

Kaliszewska, M. (2011). Funkcje eseju pedagogicznego w dydaktyce akademickiej na tle procesów inkluzji społecznej. Kielce: Wydawnictwo Uniwersytetu Humanistyczno-Przyrodniczego Jana Kochanowskiego.

Kamińska-Berezowska, S., \& Klimczak-Ziółek, J. (2007). Teoria ugruntowana w badaniach społecznego świata zabaw i zabawek dzieci - procedury metodologiczne. In M. Chomczyńska-Rubacha (Ed.), Teoretyczne perspektywy badań nad edukacją rodzajową. Łódź: Wyd. Wyższej Szkoły Humanistyczno-Ekonomicznej w Łodzi.

Kawka, M. (2012). Sześć dyskursów o języku. Skopije: Menora.

Kochanowski, J. (2004). Fantazmat zróżnicowany: socjologiczne studium przemian tożsamości gejów. Kraków: Universitas.

Kochanowski, J. (2009). Spektakl i wiedza: perspektywa społecznej teorii queer. Łódź: WschódZachód.

Kochanowski, J. (2013). Socjologia seksualności: marginesy. Warszawa: PWN.

Kopciewicz, L. (2007). Rodzaj i edukacja. Studium fenomenograficzne z zastosowaniem teorii społecznej Pierre'a Bourdieu. Wrocław: DSWE.

Kopciewicz, L. (2011). Nauczycielskie poniżanie. Szkolna przemoc wobec dziewcząt. Warszawa: Difin S.A.

Krasuska, K. (2014). Jaki gender jest, każdy widzi. In Gender. Przewodnik krytyki politycznej. Warszawa: Wydawnictwo Krytyki Politycznej.

Kuby, G. (2013). Globalna rewolucja seksualna. Likwidacja wolności w imię wolności. Kraków: Homo Dei.

Kwak, A. (1994). Rodzina i jej przemiany. Warszawa: ISNS UW.

Kwiatkowska, H. (2005). Tożsamość nauczycieli. Między anomiq a autonomiq̨. Gdańsk: GWP.

Kwiatkowska, H. (2008). Pedeutologia. Warszawa: Wyd. Akademickie i Profesjonalne.

Leach, F. (2003). Practising gender analysis in education. Oxford: Oxfam GB.

Majka-Rostek, D. (2002). Mniejszość kulturowa w warunkach pluralizacji: socjologiczna analiza sytuacji homoseksualistów polskich. Wrocław: UW.

Majka-Rostek, D. (2008). Zwiq̨zki homoseksualne: studium socjologiczne. Warszawa: Difin.

Marynowicz-Hetka, E. (2006). Pedagogika społeczna: Podręcznik akademicki. Warszawa: Wyd. Naukowe PWN.

Matland, R. E., Montgomery, K. A., \& Siemieńska-Żochowska, R. (2003). Women's acces to political power in post-communist Europe. Oxford: Oxford University Press. 
Melosik, Z. (1994). Poststrukturalizm i społeczeństwo (refleksje nad teorią M. Foucaulta). In J. Brzeziński \& L. Witkowski (Eds.), Edukacja wobec zmiany społecznej (s. 200-226). Poznań-Toruń: EDYTOR.

Melosik, Z. (2002). Kryzys męskości w kulturze wspótczesnej. Poznań: Wolumin.

Morciniec, P. (2007). Płciowość w teorii gender - krytyka i bilans skutków. In P. Morciniec (Ed.), Miłość - Płciowość - Płodność. Aktualne problemy etyki seksualnej (s. 117-129). Opole: Redakcja Wydawnictw Wydziału Teologicznego UO.

Morciniec, P. (2008). Rodzina wobec idei gender. In D. Bryl \& J. Troska (Eds.), Teologia i Moralność (s. 151-166). Poznań: Uniwersytet im. Adama Mickiewicza.

Morciniec, P. (2010). Porażki wychowania seksualnego - wybrane zjawiska i scenariusze naprawcze. In K. Glombik (Ed.), Wychowanie seksualne w rodzinie i w szkole (s. 175-189). Opole: Wydawnictwo Uniwersytetu Opolskiego.

Morciniec P. (2011). Małżeństwo i rodzina w zderzeniu z gender. In A. Bartoszek (Ed.), Familiaris splendor. Piękno życia rodzinnego jako wyzwanie dla społeczeństwa i Kościoła (s. 71-88). Piekary: Księgarnia św. Jacka. Dostupné z http://www.wtl.us.edu.pl/stih/1,2/ STiH_01,2\%282011\%2971-88.pdf

Nagórny, J., \& Pokrywka, M. (Ed.). (2005). Płciowość ludzka w kontekście miłości. Przesłanie moralne Kościoła. Lublin: Wydawnictwo KUL.

Pankowska, D. (2005). Wychowanie a role płciowe: Pedagogika gender. Gdańsk: Gdańskie Wydawnictwo Psychologiczne.

Pokrywka, M. (2012). Mężczyzna i kobieta w poszukiwaniu własnej tożsamości. In K. Jeżyna \& M. Pokrywka (Eds.), Współczesne oblicza seksualności. Przesłanie moralne Kościoł (s. 13-34). Lublin: Wydawnictwo KUL.

Radkiewicz, M. (2002). Gender-kultura-społeczeństwo. Kraków: Rabid.

Radkiewicz, M. (Ed.). (2003). Gender w kulturze popularnej. Kraków: Rabid.

Radkiewicz, M. (Ed.). (2004). Gender - konteksty. Kraków: Rabid.

Radkiewicz, M. (2006). „Młode wilki” polskiego kina: kategoria gender a debiuty lat 90 . Kraków: Wyd. UJ.

Radkiewicz, M. (2014). Oblicza kina queer. Kraków: Korporacja Ha!art.

Siemieńska, R. (1997a). Płeć a wybory: od wyborów parlamentarnych do wyborów prezydenckich. Warszawa: ISS.

Siemieńska, R. (Ed). (1997b). Portrety kobiet i mężczyzn w środkach masowego przekazu oraz podręcznikach szkolnych: praca zbiorowa. Warszawa: Scholar.

Siemieńska, R. (1999). Women and men in elites: Cross national study. Warsaw: Fundacja im. F. Eberta.

Siemieńska-Żochowska, R. (2000). Nie mogq, nie chcq czy nie potrafiq?: o postawach i uczestnictwie politycznym kobiet $w$ Polsce. Warszawa: Scholar.

Sierakowski, S. (2014). Gender Kościoła polskiego. Wstęp. In Gender. Przewodnik krytyki politycznej. Warszawa: Wydawnictwo Krytyki Politycznej.

Slany, K. (2013). Zagadnienia małżeństwa i rodziny w perspektywie feministyczno-genderowej. Kraków: NOMOS.

Slany, K., Struzik, J., \& Wojnicka, K. (Eds.). (2011). Gender w społeczeństwie polskim, Kraków: NOMOS. 
Śliwerski, B. (Ed.). (2010). Pedagogika: subdyscypliny i dziedziny wiedzy o edukacji. Gdańsk: GWP Pedagogika.

Suchodolski, B. (1983). Dwa bieguny ludzkiej egzystencji. Kwartalnik Pedagogiczny, (3-4).

Szafulski, A. (2008). Ideologia gender i płynące z niej zagrożenia. In D. Bryl \& J. Troska (Eds.), Teologia i Moralność, t. 3 (s. 167-178). Poznan: Uniwersytet im. Adama Mickiewicza.

Ślęczka K. (1999). Feminizm: ideologie i koncepcje społeczne współczesnego feminizmu, Wyd. Książnica, Katowice.

Titkow, A. (2007). Tożsamość polskich kobiet: ciagłość, zmiana, konteksty. Warszawa: Wyd. Instytut Filozofii i Socjologii.

Titkow, A. \& Domański, H. (Eds.). (1995). Co to znaczy być kobieta w Polsce. Warszawa: IFiS PAN.

Titkow, A., Duch-Krzysztoszek, D., \& Budrowska, B. (2004). Nieodpłatna praca kobiet: mity, realia, perspektywy. Warszawa: Wyd. Instytutu Filozofii i Socjologii PAN.

Witkowski, L. (1995). Ambiwalencja tożsamości z pogranicza kulturowego. In M. M. Urlińska (Ed.), Edukacja a tożsamość etniczna. Materiały z konferencji naukowej w Rabce. Toruń: Uniwersytet Mikołaja Kopernika.

Witkowski, L. (1994a). Ambiwalencja jako kategoria dla socjologii edukacji. In J. Brzeziński \& L. Witkowski (Eds.), Edukacja wobec zmiany społecznej (s. 189-199). Poznań-Toruń: EDYTOR.

Witkowski, L. (1994b). Ambiwalencja i sacrum. O religioznawczym wyzwaniu M. Eliade dla pedagogiki. In Z. Kwieciński (Ed.), Nieobecne dyskursy (s. 47-61). Toruń: Uniwersytet Mikołaja Kopernika.

Witkowski, L. (1998). Edukacja wobec sporów o (po)nowoczesność. Warszawa: IBE.

Witkowski, L. (2001). Dwoistość w pedagogice Bogdana Suchodolskiego (z aneksem o Sergiuszu Hessenie). Kraków: WIT-GRAF.

Witkowski, L. (2013). Przełom dwoistości w pedagogice polskiej: Historia, teoria, krytyka. Kraków: Oficyna Impuls.

Wołoszyn, S. (1998). Pedagogiczne wędrówki przez wieki i zagadnienia. Studia i szkice. Toruń: Wyd. A. Marszałek.

Zamojska, E. (2011). Ideologie edukacyjne a konstruowanie podręczników szkolnych. In M. Chomczyńska-Rubacha (Ed.), Podręczniki i poradniki. Konteksty. Dyskursy. Perspektywy. Kraków: Oficyna Impuls.

Zierkiewicz, E. (Ed.). (2010). Świat (z) kolorowych czasopism: prasa dla kobiet i dziewczyn $w$ perspektywie interdyscyplinarnej. Wrocław: Atut.

Zierkiewicz, E., \& Łysak, A. (Eds.). (2007). Kobieta i (b)rak: wizerunki raka piersi w kulturze. Wrocław: MarMar.

\section{Autorka}

Dr. Małgorzata Kaliszewska, Instytut pedagogiki i psychologii, ul. Krakowska 11, 25-029 Kielce, Polska, e-mail: rita02@wp.pl 